\title{
Cerebrospinal fluid dynamics at the lumbosacral level in patients with spinal stenosis
}

\author{
Keewon Kim ${ }^{*}$, Dong-Joo Kim², Kwang Dong Kim', Hack-Jin Lee², Chul-Ho Sohn', Sun-Gun Chung ${ }^{1}$, \\ Se-Woong Chun ${ }^{1}$, Ho NamKoong ${ }^{1}$ \\ From Hydrocephalus 2015 \\ Banff, Canada. 18-21 September 2015
}

\section{Introduction}

The hydrodynamics of the cerebrospinal fluid (CSF) is well-known to contribute to neurological disorders of the brain. However, little attention has been paid to the CSF dynamics in the lumbosacral spine. Meanwhile, the pathomechanism of neurogenic claudication, a characteristic symptom of spinal stenosis, has not been clearly elucidated. In this study, we suspected that spinal stenosis may be associated with altered CSF dynamics and compared CSF flow velocities at the lumbosacral spinal level between patients with spinal stenosis and healthy controls, at rest and at claudication.

\section{Methods}

Twelve subjects (4 patients with spinal stenosis and 8 healthy controls; 25-77 years old; 7 males) underwent phase-contrast magnetic resonance imaging (PC-MRI) to quantify CSF dynamics at the lumbosacral spinal level. Using PC-MRI, the CSF flow velocities were measured at the L2 and S1 levels. All of the subjects underwent PC-MRI at rest and after walking (to provoke neurogenic claudication in the patients).

\section{Results}

The flow rate in the sacral spine (caudal peak flow: $-0.25 \pm$ $0.28 \mathrm{~cm} / \mathrm{s}$ ) was greatly attenuated compared to the flow in the lumbar spine (caudal peak flow: $-0.93 \pm 0.46 \mathrm{~cm} / \mathrm{s}$ ) in both patients and controls. The caudal peak flow was slower in patients $(-0.65 \pm 0.22 \mathrm{~cm} / \mathrm{s})$ than controls $(-1.07$ $\pm 0.49 \mathrm{~cm} / \mathrm{s})$. The difference between the $\mathrm{L} 2$ caudal peak flow became more pronounced after walking $(-0.66 \pm 0.37$ $\mathrm{cm} / \mathrm{s}$ in patients, $-1.35 \pm 0.52 \mathrm{~cm} / \mathrm{s}$ in controls; $\mathrm{p}=0.028)$. The sacral CSF flow after walking was barely detectable in

* Correspondence: keewonkimm.d@gmail.com

${ }^{1}$ Seoul National University Hospital, Korea, Republic of (South Korea

Full list of author information is available at the end of the article patients (caudal peak flow: $-0.09 \pm 0.03 \mathrm{~cm} / \mathrm{s}$ ) compared with controls (caudal peak flow: $-0.32 \pm 0.26 \mathrm{~cm} / \mathrm{s}$ ). The severity of structural stenosis (area or AP diameter of the spinal canal) did not correlate with the flow velocities within the participants.

\section{Conclusions}

CSF dynamics in the lumbosacral spine were more attenuated in patients with spinal stenosis than healthy controls in a manner that was not proportionate to the structural stenoses. After walking, the CSF flow rate did not exhibit an appropriate increase in patients experiencing claudication, whereas the flow rate did increase appropriately in controls. Altered CSF dynamics may partially explain the pathophysiology of spinal stenosis.

\section{Authors' details \\ ${ }^{1}$ Seoul National University Hospital, Korea, Republic of (South Korea. ${ }^{2}$ Department of Brain and Cognitive Engineering, Korea University, Korea, Republic of (South Korea.}

Published: 18 September 2015

\section{References}

1. Lee SH, Yoon C, Chung SG, Kim HC, Kwak Y, Park HW, Kim K: Measurement of Shoulder Range of Motion in Patients with Adhesive Capsulitis Using a Kinect. PLoS One 2015, 10(6).

2. Capsule Preservation Improves Short-term Outcome of Hydraulic Distension in Painful Stiff Shoulder. J Orthop Res 2011.

3. Yi Y, Jeong WJ, Kim W, Kim K: Contralateral Reinnervation in Patients with Facial Nerve Palsy. Otology \& Neurotology 2014.

4. Neuronox versus BOTOX for spastic equinus gait in children with cerebral palsy: a randomized, double-blinded, controlled multicentre clinical trial. Dev Med Child Neurol 2011, 53(3):239-44.

5. Cho $Y$, Lee $G$, Aguinaldo J, Lee KJ, Kim K: Correlates of bone mineral density and sagittal spinal balance in the aged. Ann Rehabil Med 2015, 39(1).

6. Cauda equina syndrome misdiagnosed as aggravated hydrocephalus: neurological complication of intrathecal colistin in post-surgical meningitis. Acta Neurochir (Wien) 2011, 153(2):425-7, Epub 2010 Sep 26. 
7. Yi Y, Kang HJ, Shin HY, Kim K: Progressive Myelopathy Mimicking Subacute Combined Degeneration after Intrathecal Chemotherapy. Journal of Child Neurology 2014.

8. Choi YA, Kim K, PM R: Sciatic Neuropathy Caused by Focal Venous Engorgement Associated with Deep Vein Thrombosis: A Case Report. 2015.

9. Shim JS, Chung SG, Bang H, Lee HJ, Kim K, PM R: Ulnar Neuropathy After Extracorporeal Shockwave Therapy: A Case Report. 2015, 7(6).

10. Seo HG, Oh BM, Kim K, PM R: Robot-assisted gait training in a patient with hereditary spastic paraplegia. 2015, 7(2):210-3

11. A case of symptomatic cervical perineural (Tarlov) cyst: clinical manifestation and management. Skeletal Radiol 2012

12. Diagnosis and management of muscle pain. J Korean Med Assoc 2013.

doi:10.1186/2045-8118-12-S1-P24

Cite this article as: Kim et al.: Cerebrospinal fluid dynamics at the lumbosacral level in patients with spinal stenosis. Fluids and Barriers of the CNS 2015 12(Suppl 1):P24

\section{Submit your next manuscript to BioMed Central} and take full advantage of:

- Convenient online submission

- Thorough peer review

- No space constraints or color figure charges

- Immediate publication on acceptance

- Inclusion in PubMed, CAS, Scopus and Google Scholar

- Research which is freely available for redistribution

Submit your manuscript at www.biomedcentral.com/submit 